\title{
Optimal Parameter Determination on Friction Stir Welding Process of AA6061 using Grey Taguchi Method
}

\author{
P. Gopu, M. Dev Anand
}

\begin{abstract}
The Friction Stir Welding (FSW) process is an innovative technique to join metals in the plasticity field, thus not reaching the melting temperature and consequently the liquid state as it happen in traditional welding processes. This feature of the FSW proved an enhancement of the fatigue behavior and strength of the joints, leading some companies to adopt the process for the manufacturing of airplanes fuselages and cryogenic tanks for Space launch vehicles. The ultimate goal of this paper is to determine the optimal influencing parameter of Friction Stir welding process using Taguchi method of optimization. Here we used L9 Taguchi orthogonal design for designing the experiment. Three major controllable parameters are welding speed or feed, rotational speed and length of the tool pin are used for the present work. To convert the multi objectives like Tensile strength and the Hardness of the welded work pieces, Grey relation analysis is used. The graph plots the Signal to Noise ratio which identifies the optimal process parameters. The work material used for experimental work is aluminium alloy $A A$ 6061.
\end{abstract}

Keywords--- Friction Stir Joining Process, Grey Relation Analysis, Taguchi Method.

\section{INTRODUCTION}

Friction Stir welding process is a novel material joining process invented by Thomas et al., [14] in 1991. The Material subjected to Friction Stir Welding does not melting and recasting and hence the resultant welding offers merits over conventional arc welding, such as good mechanical properties at weld zone and relatively very low weld defects. In recent years Friction Stir Welding has become one of the most needed solid state joining process, and it requires considerably very less energy. No shielding gas or flux is needed, thereby making the process environmental friendly. The principle behind friction stir welding process is hot shear work of the work pieces and tool. Here a tool which is rotated at high speed and moves to plunges in to the joining part of the work pieces already clamped at rigid position. Here tool have a small pin and which initially drill one end of the welding area and then the rotating tool is moved along in the direction of the weld. During that time friction is developed between the tool and work pieces and which in turn create high temperature in the work pieces. With the application of the forging pressure the two work pieces were welded. The detailed work carried out in this research has been pointed out in the below flow chart as shown in the Figure 1.

Revised Manuscript Received on July 10, 2019.

P. Gopu, Assistant Professor, Mechanical Engineering Sandwich Nagar, Tamil Nadu, India. (e-mail: gopu91@ @otmail.com)

M. Dev Anand, Professor and Director Research, Department of Mechanical Engineering, Noorul Islam Centre for Higher Eduacation, Kumaracoil, Tamilnadu, India. Department, Lord Jegannath College of Engineering and Technology, PSN

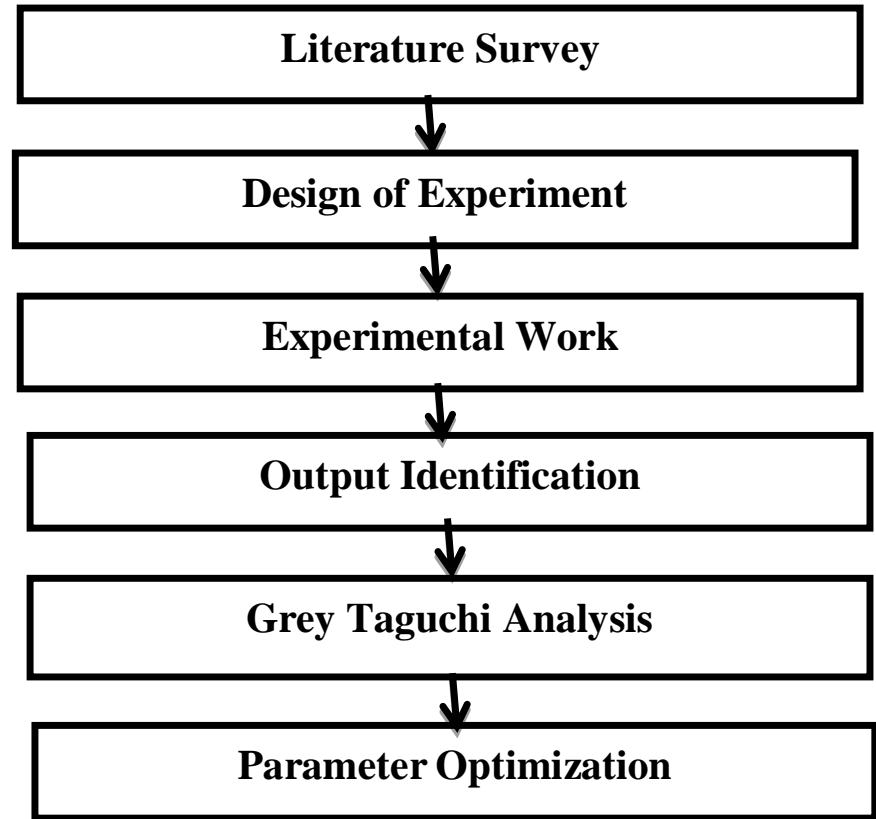

Figure 1: Research Methodology

\section{PAST EXPERIENCE}

This chapter mainly focus on the past experience of the researcher's search on friction stir welding investigation with the consideration of different parameters and the identification of Taguchi method used in different application. Prasanna et al., [1] was optimized the process parameters of the friction stir welding using AA 6061 alloy. They consider speed of rotation, welding speed, tool pin length and offset distance are the input process parameters. Ultimate strength, percentage of elongation and hardness are considered as output responses. Based on the Taguchi method of optimization the optimized controllable parameters are $800 \mathrm{rpm}$ speed of rotation, $10 \mathrm{~mm} / \mathrm{min}$ welding speed, $5.7 \mathrm{~mm}$ tool pin length and $0.4 \mathrm{~mm}$ offset distance. Finally they validate the optimized parameter by modeled the experiment using Ansys simulation. Rajakumar et al., [2] was proposed an empirical relation between the controllable parameters of friction stir welding and the tensile strength of the joint using AA7075-T6 aluminium alloy. Design of experiment, analysis of variance and regression analysis are considered for made the relationship. The optimized parameters are rotational speed $1438 \mathrm{r} / \mathrm{min}$, welding speed $67.64 \mathrm{~mm} / \mathrm{min}$, axial force $8.29 \mathrm{kN}$, shoulder diameter $15.54 \mathrm{~mm}$, pin diameter $5.13 \mathrm{~mm}$, and tool material hardness $600 \mathrm{HV}$ for getting the output $375 \mathrm{MPa}$ tensile

Published By:

Blue Eyes Intelligence Engineering

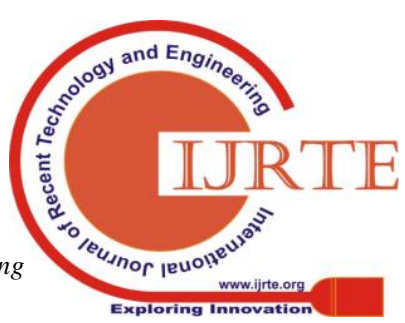


strength. Jawdat et al., [3] was developed the empirical relationship for predicted the output parameter tensile strength of the friction stir welded work pieces. Response surface methodology is used to optimize the process parameters like Rotational speed, Feed, Tool shoulder diameter and Weld plate thickness. For designing the experiment central comp0osite design with four factors are used. Muhsin et al., [4] has been conducted the three dimensional nonlinear numerical simulation of friction stir welding using AA7020-T53 for studied the variations of transient temperature. And the results showed that the temperature is equally distributed with respect to welding line, increasing travel speed decreasing transient temperature distribution and increasing rotational speed increase temperature distribution. Shiva et al., [5] was investigated the friction welding process for $\mathrm{Cu} \mathrm{Zn} 28 \mathrm{~Pb} 2$ alloy using Taguchi method of optimization. The observed results shows that that the joint exhibits good tensile strength with increase in forging pressure and medium level of rotational speed. The optimized input process parameters are speed $1500 \mathrm{rpm}$, friction time $5 \mathrm{sec}$, friction pressure 10 bar and forging pressure 30 bar. Nourani et al., [6] was reviewed the different thermo mechanical modeling techniques like Computational Solid Mechanics (CSM)based, Computational Fluid Dynamics (CFD)-based and Multiphysics (CSM-CFD) models used in friction stir welding process in past studies. Babu et al., [7] was investigated the effect of process parameters of the friction stir spot welding using AA 2014. Purushotham et al., [8] was proposed the artificial neural network model to predict the responses of the friction stir welding process for the dissimilar materials AA 2014 and AA 6061. The processing parameters like tool rotational speed, welding speed and axial force has been optimized with the help of signal to noise ratio and ANOVA. Guo et al., [9] was made an experiment to find the process parameter effect of friction stir welding in dissimilar metals of AA6061 and AA7075. With the presence of smaller grains in AA7075 Al layers grain refinement has been formed in all three layers across the nugget zone. Micro hardness of both the alloys is decreased in the welded zones compared with base metals. The joints of AA6061 Al side is fractured at the heat affected zone by the time of tensile test were conducted. Also it was found that the tensile property of the work piece is high with highest speed of welding. Deepak et al., [10] was optimized the Friction Welding process parameters for Aluminium Alloy 6082 T6 and Austenitic Stainless steel 304. The effect of parameters friction pressure, forging pressure, friction time and forging time, over tensile strength is analyzed using Response surface methodology. The tensile property of the work pieces increased as friction time and forging pressures increased and on further increase, the strength decreased.

In many industrial fields and few research oriented works Taguchi technique has been widely used. Liao et al., [11] were used the Taguchi technique to identified the optimal variable settings in Wire cut Electrical Discharge Machining. Lin et al., [12] were utilized the method to identified an optimal machining variables of a hybrid process of Electrical Discharge Machining incorporating ball-burnish machining. The original Taguchi method was

developed to optimize only a single performance characteristic. The Grey relational analysis theory posited by Deng [13] has been effectively proved to resolve the intricate interrelationships among numerous performance characteristics of the Electrical Discharge Machining process.

At this point of view there is no other investigation satisfied the optimization of process parameters in Friction Stir Welding process. The ultimate aim of this research work is to carry an experimental work in aluminium 6061 alloy of Friction Stir Welding process. Three major controllable parameters were used to optimized are rotational speed; welding speed and tool pin length for the present work. Grey Taguchi optimization has been utilized to identify the optimal input parameters.

\section{EXPERIMENTAL WORK}

For conducting the experimental work of friction stir welding AA 6061 material is used which is shown in the Figure 2. The friction stir welding experimental work has been carried out in the milling machine as shown in the below Figure 3. Here a small arrangement is made to hold the two work pieces without any slip during operation and a small variation is made in the milling tool by reduced the tool diameter in the tip of the tool and pin like structure is produced. Initially the two work pieces were hold in the bed of the milling machine by a special arrangement. Then setting the parameters of the process based on L9 orthogonal array of Taguchi design of experiment as tabulated in the below Table 1.

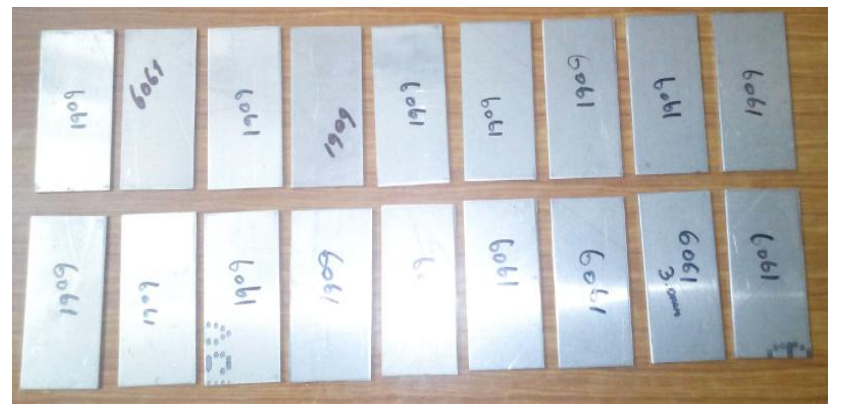

Figure 2: AA 6061 Work Pieces

Table 1: Controllable Parameters

\begin{tabular}{|c|c|c|c|}
\hline $\begin{array}{c}\text { Sl. } \\
\text { No. }\end{array}$ & $\begin{array}{c}\text { Rotational } \\
\text { Speed } \\
(\mathbf{r p m})\end{array}$ & $\begin{array}{c}\text { Welding } \\
\text { Speed } \\
(\mathbf{m m} / \mathbf{m i n})\end{array}$ & $\begin{array}{c}\text { Tool Pin } \\
\text { Length } \\
(\mathbf{m m})\end{array}$ \\
\hline 1. & 710 & 14 & 2.7 \\
\hline 2. & 1000 & 14 & 2.8 \\
\hline 3. & 1400 & 14 & 2.9 \\
\hline 4. & 710 & 28 & 2.8 \\
\hline 5. & 1000 & 28 & 2.9 \\
\hline 6. & 1400 & 28 & 2.7 \\
\hline 7. & 710 & 40 & 2.9 \\
\hline 8. & 1000 & 40 & 2.7 \\
\hline 9. & 1400 & 40 & 2.8 \\
\hline
\end{tabular}




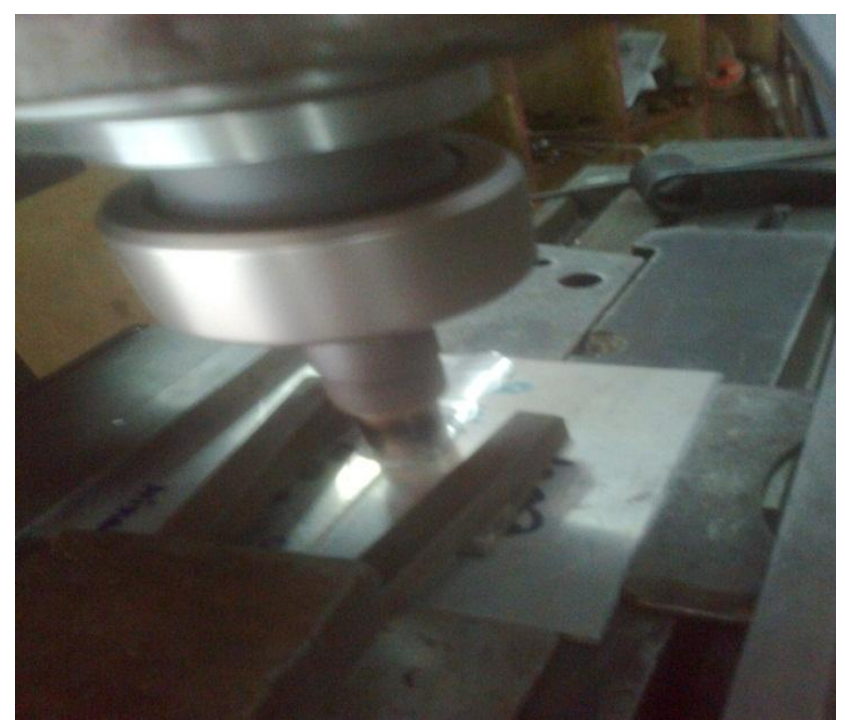

Figure 3: Operational Setup

During the process the rotational tool pin which drilling the work pieces at one end, after that the rotating tool was moved over the joint area of the work pieces over another end. At that time a huge temperature is developed over the work pieces which in turn creates a plasticized flow around the pin and with the applied pressure of the rotational tool, the friction is developed and creating the forged weld over it. Based on this experimental procedure all the nine set of work pieces were welded and to identified its mechanical characteristics tensile strength and Rockwell hardness has been carried out. The process parameter and the corresponding output responses were tabulated in the below table 2.

Table 2: process Parameter and the Corresponding Output Responses

\begin{tabular}{|c|c|c|c|c|c|}
\hline $\begin{array}{c}\text { Sl. } \\
\text { No } \\
\text { • }\end{array}$ & $\begin{array}{c}\text { Rotation } \\
\text { al Speed } \\
(\mathbf{r p m})\end{array}$ & $\begin{array}{c}\text { Welding } \\
\text { Speed } \\
(\mathbf{m m} / \mathbf{m i} \\
\mathbf{n})\end{array}$ & $\begin{array}{c}\text { Tool } \\
\mathbf{p i n} \\
\text { lengt } \\
\mathbf{h} \\
(\mathbf{m m})\end{array}$ & $\begin{array}{c}\text { Rockwel } \\
\mathbf{l} \\
\text { Hardnes } \\
\mathbf{S} \\
\mathbf{R H N}\end{array}$ & $\begin{array}{c}\text { Tensile } \\
\text { Strengt } \\
\mathbf{h} \\
\mathbf{M P a}\end{array}$ \\
\hline $\mathbf{1 .}$ & 710 & 14 & 2.7 & 141 & 122 \\
\hline $\mathbf{2 .}$ & 1000 & 14 & 2.8 & 176 & 143 \\
\hline 3. & 1400 & 14 & 2.9 & 149 & 115 \\
\hline 4. & 710 & 28 & 2.8 & 153 & 119 \\
\hline $\mathbf{5 .}$ & 1000 & 28 & 2.9 & 173 & 138 \\
\hline $\mathbf{6 .}$ & 1400 & 28 & 2.7 & 192 & 144 \\
\hline 7. & 710 & 40 & 2.9 & 190 & 145 \\
\hline $\mathbf{8 .}$ & 1000 & 40 & 2.7 & 203 & 158 \\
\hline 9. & 1400 & 40 & 2.8 & 166 & 82 \\
\hline
\end{tabular}

\section{GREY TAGUCHI ANALYSIS \& RESULTS}

Taguchi's parametric design is an effectual technique for robust design. It provides an effortless and formal qualitative optimal design at a very little price. It has been widely used for the last few decades. The biggest merits of this approach are to save the experimental time as well as the prize by finding out the significant variables. However Taguchi method has a disadvantage of optimize only a single performance output variable. To overcome that

disadvantage, Grey relational analysis method was used to solve the intricate interrelationship among the numerous performance oriented characteristics. The steps used to carry out the grey relation analysis have been pointed out here.

(i) Initially the two output responses were normalized by using the formula.

$\mathrm{Y}_{\mathrm{i}}=\left(\mathrm{X}_{\mathrm{i}}\right.$-Minimum of $\left.\mathrm{X}_{\mathrm{i}}\right) /\left(\right.$ Maximum of $\mathrm{X}_{\mathrm{i}}$-Minimum of $X_{i}$ )

Where

$\mathrm{Y}_{\mathrm{i}}$ is the normalized value

$\mathrm{X}_{\mathrm{i}}$ is the output values $\mathrm{i}=1,2,3, \ldots \mathrm{n}$.

Table 3: Normalized Responses

\begin{tabular}{|c|c|c|c|c|c|}
\hline $\begin{array}{l}\text { Sl. } \\
\text { N } \\
\text { o. }\end{array}$ & $\begin{array}{l}\text { Rotatio } \\
\text { nal } \\
\text { Speed } \\
(\mathbf{r p m})\end{array}$ & $\begin{array}{c}\text { Weldin } \\
\text { g Speed } \\
(\mathbf{m m} / \mathbf{m i} \\
\mathbf{n})\end{array}$ & $\begin{array}{l}\text { Tool } \\
\text { Pin } \\
\text { Leng } \\
\text { th } \\
(\mathbf{m m}) \\
\end{array}$ & $\begin{array}{c}\begin{array}{c}\text { Normaliz } \\
\text { ed }\end{array} \\
\text { Rockwell } \\
\text { Hardness } \\
\text { RHN } \\
\end{array}$ & $\begin{array}{c}\begin{array}{c}\text { Normaliz } \\
\text { ed }\end{array} \\
\text { Tensile } \\
\text { Strength } \\
\text { MPa } \\
\end{array}$ \\
\hline 1. & 710 & 14 & 2.7 & 0 & 0.526 \\
\hline 2. & 1000 & 14 & 2.8 & 0.565 & 0.803 \\
\hline 3. & 1400 & 14 & 2.9 & 0.129 & 0.434 \\
\hline 4. & 710 & 28 & 2.8 & 0.194 & 0.487 \\
\hline 5. & 1000 & 28 & 2.9 & 0.516 & 0.737 \\
\hline 6. & 1400 & 28 & 2.7 & 0.825 & 0.816 \\
\hline 7. & 710 & 40 & 2.9 & 0.790 & 0.829 \\
\hline 8. & 1000 & 40 & 2.7 & 1 & 1 \\
\hline 9. & 1400 & 40 & 2.8 & 0.403 & 0 \\
\hline
\end{tabular}

(ii) Generating the grey relation coefficient for the normalized responses using the below formula.

$\mathrm{C}=\left(\right.$ Minimum $\mathrm{Y}_{\mathrm{i}}+\mathrm{D}$ Maximum $) /\left(\mathrm{Y}_{\mathrm{i}}+\mathrm{D}\right.$ Maximum $)$

Where

$\mathrm{C}$ is the grey relation coefficient

$\mathrm{D}$ is the distinguishing coefficient ranges $(0 \leq \mathrm{D} \leq 1)$

Table 4: Grey Relation Coefficients for the Normalized Responses

\begin{tabular}{|c|c|c|c|c|c|}
\hline $\begin{array}{c}\text { Sl. } \\
\text { No } \\
\text { - }\end{array}$ & $\begin{array}{c}\text { Rotation } \\
\text { al Speed } \\
\text { (rpm) }\end{array}$ & $\begin{array}{c}\text { Welding } \\
\text { Speed } \\
(\mathbf{m m} / \mathbf{m i} \\
\mathbf{n})\end{array}$ & $\begin{array}{c}\text { Tool } \\
\text { Pin } \\
\text { Lengt } \\
\mathbf{h} \\
(\mathbf{m m})\end{array}$ & $\begin{array}{c}\text { Grey } \\
\text { Relation } \\
\text { Coefficien } \\
\text { ts } \\
\text { (Rockwell } \\
\text { Hardness) } \\
\text { RHN }\end{array}$ & $\begin{array}{c}\text { Grey } \\
\text { Relation } \\
\text { Coefficien } \\
\text { ts (Tensile } \\
\text { Strength) } \\
\text { MPa }\end{array}$ \\
\hline 1. & 710 & 14 & 2.7 & 1 & 0.487 \\
\hline 2. & 1000 & 14 & 2.8 & 0.470 & 0.384 \\
\hline 3. & 1400 & 14 & 2.9 & 0.795 & 0.535 \\
\hline 4. & 710 & 28 & 2.8 & 0.721 & 0.507 \\
\hline 5. & 1000 & 28 & 2.9 & 0.492 & 0.404 \\
\hline 6. & 1400 & 28 & 2.7 & 0.378 & 0.38 \\
\hline 7. & 710 & 40 & 2.9 & 0.387 & 0.376 \\
\hline $\mathbf{8 .}$ & 1000 & 40 & 2.7 & 0.333 & 0.333 \\
\hline 9. & 1400 & 40 & 2.8 & 0.553 & 1 \\
\hline
\end{tabular}


(iii) Grey relation grade calculation has been done by averaging the grey relation coefficient.

Table 5: Grey Relation Grade

\begin{tabular}{|c|c|c|c|c|}
\hline $\begin{array}{c}\text { Sl. } \\
\text { No. }\end{array}$ & $\begin{array}{c}\text { Rotational } \\
\text { Speed } \\
\text { (rpm) }\end{array}$ & $\begin{array}{c}\text { Welding } \\
\text { Speed } \\
(\mathbf{m m} / \mathbf{m i n})\end{array}$ & $\begin{array}{c}\text { Tool Pin } \\
\text { Length } \\
\text { (mm) }\end{array}$ & $\begin{array}{c}\text { Grey } \\
\text { Relation } \\
\text { Grade }\end{array}$ \\
\hline 1. & 710 & 14 & 2.7 & 0.743 \\
\hline 2. & 1000 & 14 & 2.8 & 0.427 \\
\hline 3. & 1400 & 14 & 2.9 & 0.665 \\
\hline 4. & 710 & 28 & 2.8 & 0.614 \\
\hline 5. & 1000 & 28 & 2.9 & 0.448 \\
\hline 6. & 1400 & 28 & 2.7 & 0.379 \\
\hline 7. & 710 & 40 & 2.9 & 0.382 \\
\hline 8. & 1000 & 40 & 2.7 & 0.333 \\
\hline 9. & 1400 & 40 & 2.8 & 0.777 \\
\hline
\end{tabular}

By using the above grade the process has been optimized in Taguchi method. The Signal to Noise ratio used in this work is larger is better as shown in the below figure 4. From the Main Effect plot for SN ratio of figure 5 the optimized input process parameters are rotational speed $1400 \mathrm{rpm}$, welding speed $14 \mathrm{~mm} / \mathrm{min}$ and the tool pin length $2.8 \mathrm{~mm}$.

\begin{tabular}{|c|c|c|}
\hline \multicolumn{3}{|c|}{ Analyze Taguchi Design - Options } \\
\hline Signal to Noise Ratio: & Formu & \\
\hline \multirow{2}{*}{$\begin{array}{l}\text { C Larger is better } \\
C \text { Nominal is best }\end{array}$} & $-10^{\star} \log [\operatorname{sum}[$ & \\
\hline & $-10^{\star} \log \left[s^{\star \star} 2\right]$ & \\
\hline$C$ Nominal is best & $10^{\star} \log \left(Y_{b a r}^{*}\right.$ & \\
\hline C Smaller is better & $-10^{\star} \log [\operatorname{sum}[$ & \\
\hline \multicolumn{3}{|c|}{$\Gamma$ Use adjusted formula for nominal is best } \\
\hline \multicolumn{3}{|c|}{ Г Use In[s] for all standard deviation output } \\
\hline Help & $0 \mathrm{~K}$ & Cancel \\
\hline
\end{tabular}

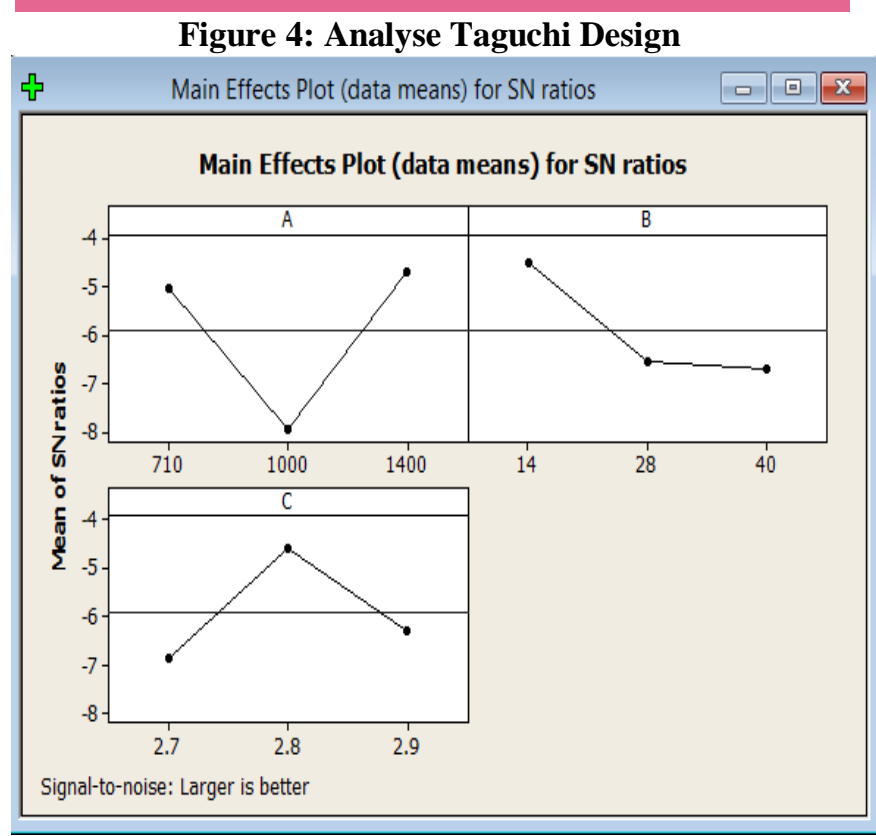

Figure 5: Main Effect Plot for SN Ratio

\section{CONCLUSION}

The friction stir welding of AA 6061 was carried out successfully in the milling machine. The characterization of the friction stir welded joints was determined through tensile strength and the hardness. In case of optimization point of view the two responses were converted in to the single response and the Taguchi based optimization was done and the optimized input parameters are rotational speed 1400 $\mathrm{rpm}$, welding speed $14 \mathrm{~mm} / \mathrm{min}$ and the tool pin length 2.8 $\mathrm{mm}$.

\section{REFERENCES}

1. P. Prasanna, Ch. Penchalayya, D. Anandamohana Rao, Optimization and Validation of Process Parameters in Friction Stir Welding on AA 6061 Aluminum Alloy Using Grey Relational Analysis, International Journal of Engineering Research and Applications, Volume 3, Issue 1, 2013, pp.1471-1481.

2. S Rajakumar, C Muralidharan, and V Balasubramanian, Optimization of the Friction-Stir-Welding Process and Tool Parameters to Attain a Maximum Tensile Strength of AA7075-T6 Aluminium Alloy, Journal of Engineering Manufacture, 2010, pp. 224: 1175.

3. Jawdat A. Al-Jarrah, Optimization of Friction Stir Welding Parameters for Joining Aluminum Alloys Using RSM, Advanced Theoretical Applied Mechanics, Volume 6, 2013, Number 1, pp. 13 - 26.

4. Muhsin J. J, Moneer H. Tolephih and Muhammed A. M, Effect of Friction Stir Welding Parameters (Rotation and Transverse) Speed on the Transient Temperature Distribution in Friction Stir Welding of AA 7020-T53, ARPN Journal of Engineering and Applied Sciences, Volume 7, Number 4, 2012, ISSN 1819-6608.

5. P. Shiva Shankar, L. Suresh Kumar, N. Ravinder Reddy, Experimental investigation and Statically Analysis of the friction Welding Parameters for the Copper Alloy - CU Zn28 Using Taguchi Method, International Journal of Research in Engineering and Technology. Volume 02, 2013, ISSN: 2319-1163.

6. M. Nourani, A. S. Milani, S. Yannacopoulos, On the Effect of Different Material Constitutive Equations in Modeling Friction Stir Welding: A Review and Comparative Study on Aluminum 6061, International Journal of Advances in Engineering and Technology, 2014, ISSN: 22311963.

7. S. Babu, V.S. Sankar, G.D. Janaki Ram, P.V. Venkitakrishnan, G. Madhusudhan Reddy, K. Prasad Rao, Microstructures and Mechanical Properties of Friction Stir Spot Welded Aluminum Alloy AA2014, Journal of Materials Engineering and Performance, Volume 22, Number 1 January 2013, pp. 71.

8. P. Purushotham, P. Hema, Effect of Friction Stir Welding on Mechanical Properties of Dissimilar Aluminium Aa6061 and Aa2014 Alloy Joints. International Journal of Engineering Sciences \& Research Technology, Volume 3, Number 4, April, 2014.

9. J.F. Guo, H.C. Chen, C.N. Sun, G. Bi, Z. Sun, J. Wei, Friction Stir Welding of Dissimilar Materials between AA6061 and AA7075 Al Alloys Effects of Process Parameters, Elsevier, Materials and Design, Volume 56, 2014, pp. 185-192. 
10. Deepak Kumar M, Venkatakrishnan P G, Optimization on Friction Welding of Aluminium Alloy 6082 T6 and Austenitic Stainless Steel 304, International Journal of Engineering Development and Research, Volume 2, Number 1 | ISSN: 2321-9939.

11. Liao Y. S, J. T. Huang and H. C. Su, A Study on the Machining - Parameters Optimization of Wire Electrical Discharge Machining, Journal of Material Processing Technology, Volume 71, 1997, pp. 487-493.

12. Lin Y. C, B. H. Yan and F. Y. Huang, Surface Modification of Al-Zn-Mg Aluminum Alloy Using combined Processes of EDM with USM, Journal of Material Processing Technology, Volume 115, 2001, pp. 359-366.

13. Deng J, Introduction to Grey System, Journal of Grey System, Volume 1, Number 1, 1989, pp. 1-24.

14. Thmoas, W. M., "Friction Stir Butt Welding, GB Patent Application”, 91259788.US Patent 995, 5460317(1991). 